\title{
Czy warto oceniać jakość zycia u dzieci z bólami głowy?
}

\section{Is it worth assessing the quality of life in children with headaches?}

\author{
Jędrzej Fliciński * (D), Dorota Talarska** (iD), Barbara Steinborn* (D) \\ *Katedra i Klinika Neurologii Wieku Rozwojowego Uniwersytet Medyczny im. Karola Marcinkowskiego w Poznaniu \\ **Katedra i Zakład Profilaktyki Zdrowotnej, Pracownia Pielęgniarstwa Społecznego Uniwersytet Medyczny im. Karola Marcin- \\ kowskiego w Poznaniu \\ DOI:10.20966/chn.2020.59.471
}

\section{STRESZCZENIE}

W artykule wymieniono najważniejsze i najczęściej używane kwestionariusze jakości życia do oceny dzieci z bólami głowy oraz przedstawiono koncepcję i definicję jakości życia. Kwestionariusze jakości życia mogą być pomocnym narzędziem w codziennej praktyce neurologa dziecięcego, mogą także służyć do oceny skuteczności wprowadzonego nowego leczenia przeciwbólowego. W artykule opisano i omówiono wyniki badań u dzieci z bólami głowy przy pomocy kwestionariuszy PedMIDAS, QLH-Y, PedsOL i CBCL.

Słowa kluczowe: jakość życia, bóle głowy, PedMIDAS, QLH-Y, PedsOL, CBCL

\section{ABSTRACT}

The article lists the most important and most frequently used quality of life questionnaires for assessing children with headaches and presents the concept and definition of quality of life. Quality of life questionnaires can be not only a helpful tool in the daily practice of a pediatric neurologist, but can also be used to assess the effectiveness of the new analgesic treatment introduced. This article describes and discusses the results of studies in children with headaches using the PedMIDAS, OLH-Y, PedsOL and CBCL questionnaires.

Key words: quality of life, headaches, PedMIDAS, QLH-Y, PedsQL, CBCL Introdukcja

\section{Wykaz skrótów:}

QL- jakość życia (ang. quality of life); IHS- Międzynarodowe Towarzystwo Bólów Głowy (ang. International Headache Society); ICHD-3 Międzynarodowa Klasyfikacja Bólów Głowy (ang. The International Classification of Headache Disorders); WHO -Światowa Organizacja Zdrowia (ang. World Health Organization); HROOL - jakości życia zależnej od stanu zdrowia (ang. Health-Related Quality of Life), PedMIDAS - Pediatryczny kwestionariusz oceny niesprawności spowodowanej migreną (ang. Pediatric Migraine Disability Specific Tool); PedsOLPediatryczny Kwestionariusz dotyczący jakości życia (ang. The Pediatric Quality of Life Inventory); QLH-Y- Jakość życia młodzieży z bólami glowy (ang. Quality of Life Headache In Youth); CBCL - Kwestionariusz zachowań dziecka (ang. Child Behavior Checklist); SF-36 - Short-Form Health Survey, NHP - Nottingham Health Profile; SGRO - St. George's Respiratory Questionnaire, LWAO- Asthma Severity Scale, Living with Asthma Questionnaire, AOLO - Asthma Quality of Live Questionnaire; MSO - Kwestionariusz Oceny Jakości Życia Swoisty dla Migreny (ang. Migraine Specific Quality of Life Questionnaire); PPAT - the Paediatric Pain Assessment Tool; OVM (fr. Qualitede Vie et Migraine); HARDSHIP - (ang. the Headache-Attributed Restriction, Disability, Social Handicap and Impaired Participation Questionnaire); WHO - Waters' Headache Questionnaire; PCQ - the Pain Coping Questionnaire; SAFA - Self Administrated Psychiatric Scales for Children and Adolescents;

\section{WPROWADZENIE:}

Bóle głowy są często dolegliwością występującą u dzieci i młodzieży a ich częstotliwość wzrasta z wiekiem [1-3]. W artykule przeglądowym analizującym 50 badań populacyjnych prawie $60 \%$ dzieci potwierdziło występowanie bólów głowy w czasie całego swojego życia [3].

W wieku 18 lat ponad 90\% młodzieży deklaruje przynajmniej jeden epizod bólu głowy [1]. Częstość nawracających bólów głowy wzrasta z wiekiem z 4,5\% wśród dzieci w wieku od 4 do 6 lat do $27,4 \%$ wśród dzieci w wieku od 16 do 18 lat. Większość raportów dotyczących epidemiologii występowania bólów głowy u dzieci podaje, że bóle głowy typu napięciowego występują 2-3 razy częściej niż migrena. [4-6]. Przegląd badań populacyjnych autorstwa Stovner i wps. wykazał, że częstość występowania bólu głowy typu napięciowego u dzieci wynosiła około $30 \%$
[4]. Z kolei w innych pracach wykazano, że przewlekły ból głowy typu napięciowego dotyczy 0,1 do 6\% dzieci [7-9]. W wieku poniżej 7 roku życia częstość występowania migreny może dotyczyć $2,5 \%$ dzieci i wraz z dorastaniem się zwiększa. U dzieci w wieku 10 lat i starszych częstość występowania migreny wynosi około 5-10\% [10-13]. Przewlekła migrena, czyli migrena występująca co najmniej 15 dni w miesiącu przez co najmniej trzy miesiące, dotyka około 1 do $2 \%$ nastolatków w wieku od 12 do 17 lat $\mathrm{i}<1 \%$ uczniów w wieku od 5 do 12 lat [14, 15]. U 20\% pacjentów stwierdzono, że przyczyną bólów głowy było nadużywanie leków przeciwbólowych. Jednak stosunkowo niewielki odsetek pacjentów jest konsultowany przez neurologa i ma włączane leczenie profilaktyczne [16]. Bóle głowy pojawiają się częściej u dzieci, które mają obciążony wywiad 
rodzinny, w badaniu Lee i wsp. dodatni wywiad rodzinny w kierunku migreny miało $65 \%$ pacjentów [17-20]. Częste występowanie bólów głowy wiąże się z częstszą nieobecnością w szkole i słabszymi wynikami w nauce. Ponad to udowodniono, że dzieci ze środowisk o niższym poziomie ekonomiczno-społecznym są w grupie podwyższonego ryzyka zachorowania na przewlekłą migrenę [14].

W pracach oceniających czynniki predysponujące do występowania migreny u dorosłych wymienia się: obciążony wywiad rodzinny, niskie dochody, niskie wykształcenie, pojawienie się bólów głowy w przeszłości [21].

Celem pracy jest przedstawienie najważniejszych kwestionariuszy jakości życia, które są wykorzystywane do oceny jakości życia u dzieci z bólami głowy.

\section{KONCEPCJA I DEFINICJA JAKOŚCI ŻYCIA}

Jakość życia (QL, ang. quality of life) jest pojęciem interdyscyplinarnym i wieloznacznie definiowanym, ponieważ może dotyczyć takich dziedzin nauki jak: medycyna, farmakologia, filozofia, psychologia, geografia, ekonomia, architektura, socjologia i między innymi dlatego w literaturze przedmiotu brak jednoznacznej definicji QL. Pierwsze wzmianki o pojęciu jakości (gr. poiotes) pochodzą z przełomu wieku III i IV przed naszą erą. W ujęciu filozoficznym pojęcie QL jako jeden z pierwszych zdefiniował Platon, dla którego jakość to „sąd wartościujący wyrażany przez osobę oraz pewien stopień doskonałości” [22]. Jednymi z pionierów obecnej definicji jakości oraz elementów składowych QL byli amerykańscy naukowcy Dalkey'a i Rourke'a, którzy w latach 70 XX wieku zdefiniowali QL, jako satysfakcję z życia i poczucie szczęścia [23]. Przełomem nad badaniami nad QL w medycynie było stworzenie w latach 50 XX definicji QL przez Światową Organizację Zdrowia (WHO, ang. World Health Organization). Dla WHO jakość życia to nie tylko brak choroby czy kalectwa, ale także stan pełnego fizycznego, umysłowego i społecznego dobrostanu [24]. W latach 90 XX wieku pojęcie QL przez WHO uległo rozszerzeniu, zwrócono uwagę na 3 aspekty QL: społeczny, psychologiczny i fizyczny, a pojęcie QL na nowo zostało zdefiniowane jako „spostrzeganie przez osobę własnej sytuacji życiowej w kontekście uwarunkowań kulturowych, systemu wartości oraz związku ze swoimi celami, normami i zainteresowaniami" [25, 26]. Encyklopedia Państwowego Wydawnictwa Naukowego (pol. PWN) definiuje QL jako „stopień zaspokojenia potrzeb materialnych i niematerialnych - spełnienie standardów lub realizacja wartości: biologicznych, psychologicznych, duchowych, społecznych i politycznych, kulturalnych, ekonomicznych i ekologicznych jednostek, rodzin i zbiorowości; to pojęcie stosowane w polityce społecznej, psychologii, medycynie, ekonomii i socjologii" [27].

Schipper jako pierwszy zdefiniował określenie jakości życia zależnej od stanu zdrowia (HRQOL, ang. Health-Related Quality of Life), jako „funkcjonalny efekt fizycznej, psychicznej i społecznej odpowiedzi na chorobę i leczenie, odbierany subiektywnie przez pacjenta, oraz ocenę własnego położenia życiowego chorego dokonaną w okresie leczenia" [28]. HRQOL obejmuje cztery obszary: stan psy- chiczny, sprawność ruchową i stan fizyczny, warunki ekonomiczne i sytuację społeczną oraz doznania somatyczne [28]. Według WHO definicja HRQOL zakłada, że każdy człowiek ma prawo do najlepszego możliwego stanu zdrowia bez względu na warunki ekonomiczne czy socjalne, religię, rasę czy przekonania polityczne [29]. Stworzona przez WHO osobna grupa zajmująca się jakością życia związaną ze zdrowiem zdefiniowała HRQOL jako pojęcie wielowymiarowe, które obejmuje szerokie obszary stanu funkcjonalnego, aspekty psychologiczne i dobrobytu społecznego, postrzeganie zdrowia, choroby i objawów związanych z leczeniem [30, 31]. W tabeli numer 1, według WHO, uwzględniono obszary QL $[32,33]$.

Zdaniem Taylor i wsp. HRQOL zależy nie tylko od stadium rozwoju, ale od przebiegu choroby i obejmuje osiąganie celów i aspiracji oraz konieczność postępowania niezwiązanego ze stanem zdrowia czy choroby i jej leczenia [34].

Zauważono, że poza biologiczną oceną zdrowia chorego istotne znaczenie mogą mieć jego odczucia emocjonalne czy możliwość funkcjonowania w życiu codziennym [35, 36]. Kluczowym elementem w tej ocenie stały się kwestionariusze jakości życia, które okazały się niezbędnym elementem oceny skuteczności zwłaszcza dla wprowadzonych nowych form terapii. W większości prowadzonych badań klinicznych nad nowymi formami terapii uczestnicy wypełniają kwestionariusze QL, które są jednym z podstaw oceny skuteczności nowego leku.

Kwestionariusze oceniające QL dzielą się na: globalne (ogólne), niespecyficzne oraz specyficzne [37]. Przykładem skali globalnej, której głównym zadaniem jest możliwość porównania danych pomiędzy różnymi grupami pacjentów, np. między grupą chorych i zdrowych są Index Jakości Życia Ferrans i Powers, Short-Form Health Survey (SF-36), Nottingham Health Profile (NHP) [37-39]. Z kolei skale niespecyficzne służą do oceny i porównania QL pomiędzy różnymi grupami chorych np. pacjentów z cukrzycą i z astmą oskrzelową. Przykładem takiego niespecyficznego narzędzia jest kwestionariusz WHOQOL-100 (ang. World Health Organization Quality of Life Instrument), który został opracowany w 1994 roku, a później powstała jego skrócona wersja WHOQOL- Bref. Celem była ocena wpływu procesu terapeutycznego oraz stanu zdrowia na QL [40, 41]. Do oceny objawów typowych dla danej jednostki chorobowej służą skale specyficzne. Takim narzędziem jest na przykład Kwestionariusz Jakości Życia Młodzieży z Bólami Głowy - (QLH-Y, ang. Quality of Life Headache In Youth Questionnaire) [42, 43], PedMIDAS (ang. Pediatric Migraine Disabiliy Specific Tool), St. George's Respiratory Questionnaire (SGRQ), Asthma Severity Scale, Living with Asthma Questionnaire (LWAQ), Asthma Quality of Live Questionnaire (AQLQ) [42, 44]. Skale specyficzne umożliwiają zobiektywizowanie oceny chorego na leczenie i porównanie QL u tych samych osób $\mathrm{z}$ tą samą dolegliwością $\mathrm{w}$ podobnym czasie.

Narzędzia stosowane do oceny QL u dzieci różnią się od tych stosowanych u dorosłych, bowiem obejmują obszary życia, które nie są uwzględniane w życiu dorosłym 
takie jak na przykład szkoła czy relacje $\mathrm{z}$ rówieśnikami lub z rodzicami. Ocena QL u dzieci nie tylko pozwala na wykrywanie zaburzeń i nieprawidłowości związanych z samą chorobą, ale także umożliwia podjęcie odpowiednich działań profilaktycznych, identyfikację społecznych i behawioralnych uwarunkowań. Stosowanie kwestionariuszy QL jest potrzebne do planowania i doskonalenia odpowiedniej opieki oraz terapii chorych dzieci, a także dla promocji zachowań zdrowotnych [45, 46].

Kompleksowa ocena QL u pacjentów z bólami głowy poza oceną medycznych aspektów takich jak zmniejszenie liczby bólów głowy, natężenia bólu głowy pozwala także na ocenę w wymiarze społecznym, emocjonalnym i duchowym. Dzięki kwestionariuszom QL jesteśmy wstanie określić w jakim stopniu choroba może wpływać na relacje z innymi ludźmi, na zdolność wyrażania emocji, ich intensywność oraz zmiany postrzegania świata. [36]. Analiza QL w bólach głowy pozwala ocenić stan zdrowia i zdolność dzieci z bólami głowy do aktywnego funkcjonowania w społeczeństwie i w środowisku jakim jest szkoła. Kompleksowa ocena leczenia dzięki pomiarowi QL pozwala na optymalny wybór leczenia i może być częścią jego efektu leczenia oraz działań niepożądanych. Wybór leku dla pacjentów z bólami głowy typu napięciowego może być częściowo określony przez intensywność oddziaływania na zaburzenia QL pacjenta.

Ocena QL u dzieci nie jest tak powszechna jak u dorosłych, zdaniem Nordani i wsp. spośród wszystkich dostępnych kwestionariuszy QL tylko 5\% jest przeznaczonych dla dzieci [43]. W przeszukiwaniu bazy danych Pubmed dla tego artykułu znaleziono tylko 59 artykułów powiązanych ze skalą PedMIDAS i aż 1379 powiązanych ze skalą MIDAS przeznaczoną dla dorosłych. Pomimo tak znacznej dysproporcji dla badań nad jakością życia u dzieci zarówno w Polsce jak i na świecie można zauważyć wzrost liczby publikacji w tym zakresie. Wśród badaczy bólów głowy najbardziej popularny jest kwestionariusz PedMIDAS (ang. Pediatric Migraine Disability Specific Tool) [44]. Poza tym stosowane są między innymi kwestionariusze: Kwestionariusz Jakości Życia Młodzieży z Bólami Głowy - (QLH-Y, ang. Quality of Life Headache In Youth Questionnaire) [42, 43, 47, 48], Kwestionariusz Oceny Jakości Życia Swoisty dla Migreny (MSQ, ang. Migraine Specific Quality of Life Questionnaire) [49], the Paediatric Pain Assessment Tool (PPAT) [50], QVM (fr. Qualitede Vie et Migraine) [51], the 24-Hour Adolescent Migraine Questionnaire [52], Child and Adolescent HARDSHIP questionnaires (ang. the Headache-Attributed Restriction, Disability, Social Handicap and Impaired Participation Questionnaire) [53], Waters' Headache Questionnaire (WHQ) [54], the Pain Coping Questionnaire (PCQ) [55].

W literaturze przedmiotu można też znaleźć kilka badań, które oceniały QL pacjentów z bólami głowy za pomocą innych kwestionariuszy globalnych takich jak Pediatryczny Kwestionariusz Dotyczący Jakości Życia (ang. The Pediatric Quality of Life Inventory, PedsQL) [56] czy Kwestionariusz Zachowań Dziecka (ang. the Child Behavior Checklist, CBCL) [57, 58].

\section{KWESTIONARIUSZ PedMIDAS}

Kwestionariusz PedMIDAS to zwalidowany dla dzieci kwestionariusz MIDAS, który powstał do badania QL dorosłych z migreną [44, 59-61]. PedMIDAS składa się

Tab. I. Obszary OL wg WHO

Areas of $Q L$ according to WHO

\begin{tabular}{|c|c|c|c|c|c|}
\hline \multicolumn{6}{|c|}{$\begin{array}{l}\text { Obszary jakości życia } \\
\text { Areas of quality of life }\end{array}$} \\
\hline $\begin{array}{l}\text { Fizyczny: } \\
\text { ból i dyskomfort, } \\
\text { witalność i } \\
\text { zmęczenie, } \\
\text { aktywność } \\
\text { seksualna, sen } \\
\text { i odpoczynek, } \\
\text { odczucia } \\
\text { sensoryczne, }\end{array}$ & $\begin{array}{l}\text { Psychiczny: } \\
\text { uczucia } \\
\text { pozytywne, } \\
\text { procesy umysłowe } \\
\text { (takie jak } \\
\text { myślenie, uczenie, } \\
\text { zapamiętywanie, } \\
\text { koncentracja), } \\
\text { obszar ciała i } \\
\text { samoocena, } \\
\text { uczucia } \\
\text { negatywne, }\end{array}$ & $\begin{array}{l}\text { Niezależności: } \\
\text { niezależność } \\
\text { ruchowa, } \\
\text { aktywność dnia } \\
\text { codziennego, } \\
\text { zależność od } \\
\text { substancji } \\
\text { medycznych } \\
\text { i pomocy } \\
\text { medycznej, } \\
\text { zależność od } \\
\text { niemedycznych } \\
\text { środków (takich } \\
\text { jak alkohol, } \\
\text { nikotyna, } \\
\text { narkotyki), } \\
\text { zdolność do } \\
\text { porozumiewania } \\
\text { się, zdolność do } \\
\text { pracy, }\end{array}$ & $\begin{array}{l}\text { Relacje społeczne: } \\
\text { osobiste relacje } \\
\text { z innymi, } \\
\text { doznawane } \\
\text { wsparcie } \\
\text { społeczne, a także } \\
\text { wspieranie innych, }\end{array}$ & $\begin{array}{l}\text { Środowisko: wolność } \\
\text { i bezpieczeństwo } \\
\text { fizyczne, środowisko } \\
\text { domowe, zadowolenie } \\
\text { z pracy, zasoby } \\
\text { finansowe, opieka } \\
\text { zdrowotna i socjalna } \\
\text { (w tym dostępność } \\
\text { i jakość opieki), } \\
\text { możliwości do } \\
\text { zdobywania nowych } \\
\text { informacji } \\
\text { i umiejętności, } \\
\text { uczestnictwo i } \\
\text { możliwości do } \\
\text { rekreacji i spędzenia } \\
\text { wolnego czasu, } \\
\text { środowisko fizyczne } \\
\text { (zanieczyszczenie/ } \\
\text { hałas/klimat), } \\
\text { transport, }\end{array}$ & $\begin{array}{l}\text { Duchowy: } \\
\text { przekonania } \\
\text { religijne bądź } \\
\text { osobiste } \\
\text { poglądy }\end{array}$ \\
\hline
\end{tabular}


z 6 pytań, które dotyczą liczby dni, w których bóle głowy przeszkadzają w funkcjonowaniu w ciągu ostatnich 3 miesięcy. Pierwsze trzy pytania dotyczą wpływu bólu głowy na funkcjonowanie w szkole. Pytanie 1 dotyczy liczby pełnych dni nieobecności w szkole. Pytanie drugie dotyczy ilości dni, w których pacjent został częściowo zwolniony z zajęć szkolnych (np. ile razy dziecko zwolnione zostało z jednej lub kilku lekcji z powodu bólu głowy), a pytanie trzecie dotyczy liczby dni, w których funkcjonowanie w szkole było ograniczone na poziomie mniejszym niż połowa swoich umiejętności. Czwarte pytanie ocenia wpływ bólu głowy na funkcjonowanie w domu i obejmuje liczbę dni, w których pacjent nie był wstanie odrabiać zadań i prac domowych. Dwa ostatnie pytania oceniają niepełnosprawność w funkcjonowaniu społecznym, w tym funkcjonowanie w zajęciach sportowych. Pytanie piąte dotyczy liczby dni całkowitej nieobecności w zajęciach pozaszkolnych, natomiast pytanie szóste dotyczy ilości dni, kiedy funkcjonowanie i uczestnictwo było ograniczone na poziomie $50 \%$ lub mniejszym w zajęciach pozaszkolnych. Kolejne dwa pytania nie są brane pod uwagę w końcowym wyniku i dotyczą częstotliwości bólów głowy w ciągu ostatnich 3 miesięcy oraz nasilenia bólów głowy podawanego w skali od 0 do 10, gdzie 0 oznacza brak bólu, a 10 najsilniejszy ból w życiu. Ostateczny wynik to suma wszystkich dni, które zaburzały funkcjonowanie w ostatnich 3 miesiącach. $\mathrm{W}$ podsumowaniu otrzymujemy informację $\mathrm{w}$ jaki sposób bóle głowy upośledzają funkcjonowanie dzieci. W PedMIDAS istnieją 4 stopnie oceny od braku wpływu, poprzez lekki, umiarkowany i silny wpływ na życie dzieci z migreną. Lekki stopień niepełnosprawności otrzymuje pacjent, który otrzymał wyniki od 0 do 10 dni. W przypadku zaznaczenia od 11 do 30 dni stopień niepełnosprawności ocenia się na łagodny, od 31 do 50 dnia na umiarkowany, a występowanie powyżej 50 dni ocenia się jako ciężki stopień niepełnosprawności. Uzyskanie wyższych wyników w kwestionariuszu PedMIDAS zdaniem Hershey i wsp. jest wskazaniem do włączenia leczenia profilaktycznego [59].

Kwestionariusz PedMIDAS był używany do oceny skuteczności takich leków jak: topiramat, propranolol, flunaryzyna, amitryptylina, melatonina, lewetyracetam, koenzym Q10 [62-66]. Szperka i wsp. rekomendują zastosowanie przeciwciał monoklonalnych przeciwko peptydowi pochodnemu genowi kalcytoniny (ang. calcitonin gene-related peptide, CGRP) u dorastających nastolatków $\mathrm{z}$ częstymi atakami migreny $(\geq 8$ bólów głowy w ciągu miesiąca), u których stopień niepełnosprawności związany z migreną jest umiarkowany do ciężkiego na podstawie wyników kwestionariusza PedMIDAS (wynik PedMIDAS $\geq 30$ ) i braku efektu $\geq 2$ terapii zapobiegawczych (farmakologiczne, nutraceutyczne i/lub niefarmakologiczne) [67]. Stosowanie kwestionariusza PedMIDAS jest rekomendowane w wytycznych opublikowanych przez IHS dotyczących przeprowadzania badań nad leczeniem profilaktycznym w migreny u dzieci i młodzieży [68]. Wadą kwestionariusza PedMIDAS, na co zwraca uwagę Heyer i wsp., jest fakt, że PedMIDAS nie ocenia niepełnosprawności związanej z bólem głowy w dni pozaszkolne i w związku z tym ocena PedMIDAS podczas roku szkolnego może nie być porównywalna z ocenami dokonanymi podczas wakacji [69]. Heyer i wsp. uważają, że te potencjalne różnice należy wziąć pod uwagę, używając PedMIDAS jako narzędzia do oceny wyników badań klinicznych [69]. Kolejną wadą PedMIDAS jest fakt, że jest to narzędzie, które skupia się tylko na ocenie niepełnosprawności związanej z bólem głowy pomijając inne aspekty QL. Niestety, według wiedzy autorów tego artykułu, kwestionariusz PedMIDAS nie został przetłumaczony i zwalidowany na język polski.

W badaniu Bektas i wsp. oceniającym związek bólów głowy z preferencjami dotyczącymi spędzania wolnego czasu, stwierdzono, że dzieci, które wybierały sport jako formę spędzania czasu miały lepsze wyniki w skali PedMIDAS niż dzieci, który wybierały czytanie książek, oglądanie telewizji czy granie na komputerze [70]. Autorzy podkreślają, że uprawianie sportu może pozytywnie wpłynąć na częstotliwość epizodów migrenowych, a zmniejszenie wysiłku fizycznego może być czynnikiem pogarszającym migrenowe bóle głowy. Tryptany stanowią ,złoty standard” w leczeniu migreny jednak grupa dzieci z migreną charakteryzuje się stosunkową wysoką odpowiedzią na placebo. Zdaniem Hershey’a leczenie doraźne nie wpływa tak na poprawę QL jak włącznie leczenia profilaktycznego [44].

\section{KWESTIONARIUSZ JAKOŚCI ŻYCIA MŁODZIEŻY Z BÓLAMI GŁOWY}

Kwestionariusz Jakości Życia Młodzieży z Bólami Głowy (QLH-Y, ang. Quality of Life Headache In Youth) zawiera 71 pytań w tym 2 wizualne analogowe skale 100 mm (VAS, ang. Visual Analogue Scale) oceniające poczucie ogólnej satysfakcji ze swojego zdrowia i życia [42, 43]. QLH-Y jest przeznaczony dla młodzieży z bólami w wieku od 12-17 lat, a jego wypełnienie zajmuje około $10 \mathrm{mi}$ nut. Ze wszystkich kwestionariuszy QL u dzieci z bólami głowy jest to najdokładniejsze i najbardziej szczegółowe narzędzie. QLH-Y ocenia 6 głównych aspektów QL: funkcjonowanie psychologiczne, stanu funkcjonalny, funkcjonowanie fizyczne, funkcjonowanie społeczne, ogólne zadowolenia z życia, ogólne poczucia własnego zdrowia. W QLH-Y zawartych jest 13 podskal, które są przyporządkowane do odpowiednich skal. Do skali funkcjonowania psychologicznego zaliczono podskale: stresu (8 pytań), harmonii (5 pytań), zmęczenia (4 pytania), witalności (3 pytania), depresji (6 pytań), dobrego nastroju i dobrego humoru (4 pytania), optymizmu związanego z przyszłością (3 pytania). Do skali dotyczącej stanu funkcjonalnego zaliczono podskale wpływu bólów głowy na codzienną aktywność (8 pytań) i wpływu bólu głowy na spędzanie wolnego czasu (6 pytań). Do skali funkcjonowania społecznego zaliczono podskale funkcjonowania w domu i w szkole (6 pytań), społecznych interakcji z braćmi lub siostrami (3 pytania), społecznych interakcji z rówieśnikami (3 pytania). Pytania dotyczą funkcjonowania $\mathrm{z}$ bólami głowy w ostatnim tygodniu i do każdego pytania chory wybierał tylko jedną odpowiedź z możliwością odpowiedzi w 4 stopniowej skali (0-3). Algorytm kwestionariusza QLH-Y polega na podliczeniu wszystkich punktów w danej podskali lub skali 
i podzieleniu otrzymanego wyniku przez liczbę odpowiedzi. Wyższe wyniki w podskalach stresu, zmęczenia, depresji, wpływu bólu głowy na aktywności oraz na spędzania wolnego czasu oznaczają gorszą QL, natomiast w pozostałych podskalach wyższe wyniki oznaczają lepszą QL.

Dzięki kwestionariuszowi QLH-Y Langeveld i wsp. wykazali, że holenderscy nastolatkowie w wieku od 12 do 18 lat z bólem głowy odczuwali większy stres i zmęczenie oraz gorszy nastrój niż nastolatki, które nie odczuwały bólu głowy [48]. Cotygodniowe oceny QL wskazywały ponadto, że bóle głowy miały negatywny wpływ na codzienne czynności nastolatków i czas wolny. Podobne wyniki QL u dzieci z bólami głowy uzyskali Nodari i wsp. u włoskich nastolatków [43]. W innym badaniu Langeveld i wsp. stwierdzili, że wraz z nasileniem się migren i częstości ich występowania występuje negatywny wpływ na codzienne czynności, zmęczenie, szczęście i nastrój, a nastolatkowie zgłaszali mniejszą satysfakcję poczucia swojego zdrowia i zycia na skali VAS [42].

\section{KWESTIONARIUSZ PEDSQL}

Kwestionariusz PedsQL składa się z 23 pytań i jest przeznaczony do oceny QL dzieci od 2 do 18 roku życia oraz ich opiekunów, przy czym od 2 do 4 roku życia kwestionariusz wypełniają tylko rodzice [71]. Najnowsza wersja 4.0 kwestionariusza PedsQL występuje w czterech różnych wersjach w zależności od wieku: dla małych dzieci w wieku 2-4 lat, dla dzieci w wieku 5-7 lat i w wieku 8-12 lat oraz dla młodzieży w wieku 13-18 lat. PedsQL jest przeznaczony zarówno dla zdrowych jak i chorych dzieci z ostrymi lub przewlekłymi chorobami. Wypełnienie kwestionariusza PedsQL zajmuje około 4 minuty, a pytania dotyczą takich obszarów QL jak: funkcjonowanie w sferze fizycznej (8 pytań), emocjonalnej (5 pytań), społecznej (5 pytań) i w szkole (5 pytań). W sumie 8 pytań dotyczy stanu zdrowia fizycznego i 15 zdrowia psychospołecznego. W najnowszej wersji PedsQL 4.0 pytania dotyczą funkcjonowania w ciągu ostatniego miesiąca. Dzieci w wieku 5-7 lat odpowiadają na pytania w 3 punktowej skali Likerta, a dzieci w wieku 8-18 lat w 5 stopniowej skali, gdzie 0 oznacza, że wymieniony problem nigdy nie sprawiał kłopotu, 1- problem prawie nigdy nie sprawiał kłopotu, 2 problem czasami sprawiał kłopot, 3 - problem często sprawiał kłopot, 4 - problem prawie zawsze sprawiał kłopot. Uzyskane wyniki są przekształcane w wynik standaryzowany do odwróconej skali od 0 do $100(0=100,1=75$, $2=50,3=25,4=0$ ), dzięki czemu uzyskuje się wyniki znormalizowane o średniej równej 50. Uzyskanie wyższego wyniku wskazuje na lepszą HRQOL (jakość życia związana ze zdrowiem) [72]. Kwestionariusz PedsQL został przetłumaczony i zwalidowany na język polski [73-75].

W badaniu Talarskiej i wsp. [74], które przy pomocy kwestionariusza PedsQL badało QL dzieci z bólami głowy typu napięciowego wzięło udział 221 dzieci, z czego 86 stanowiła grupa $\mathrm{z}$ bólami głowy typu napięciowego a 135 to była grupa kontrolna. We wnioskach stwierdzono, że dzieci z bólem głowy typu napięciowego w porównaniu ze zdrowymi rówieśnikami gorzej funkcjonowały w zakresie emocjonalnym i miały gorszy nastrój. Dzieci z bólami głowy typu napięciowego częściej zgłaszała uczucie lęku i zaburzenia snu. Poza tym dzieci z bólami głowy postrzegają swoją przyszłość bardziej pesymistycznie i były mniej zadowolone ze swojego życia. W innym badaniu Talarskiej i wsp., wzięło udział 117 dzieci z bólem głowy typu napięciowego lub z migreną. U prawie $60 \%$ dzieci z bólami głowy występowała ospałość, u 75\% poczucie strachu, a uczucie złości towarzyszyło $62 \%$ badanych [73]. W badanej grupie na trudności w zasypianiu lub koszmary senne wskazało $46 \%$ dzieci. Wśród problemów szkolnych, najczęściej podkreślanych przez młodzież, była niższa koncentracja (25\%) i uzyskiwanie gorszych ocen (17\%). Z powodu bólu głowy $22 \%$ respondentów czasami nie uczestniczyło w zajęciach szkolnych. Zadowolenie z życia zadeklarowało niewiele ponad połowę objętych badaniem dzieci, tj. 55\%. W badaniu Talarskiej i wsp. nie stwierdzono różnic $\mathrm{w}$ ocenie funkcjonowania w poszczególnych obszarach kwestionariusza w zależności od rodzaju bólów głowy [73].

Autorzy kwestionariusza PedsQL, czyli Powers i wsp. stwierdzili, że u dzieci z migreną istniała różnica w ocenie QL w zależności od wieku [76]. W badaniu wzięło udział 686 dzieci, nastolatki (13-18 lat) miały gorsze wyniki w funkcjonowaniu w szkole oraz w skalach oceniających funkcjonowanie fizyczne niż młodsze dzieci. Z kolei najmłodsze dzieci (5-7 lat) miały więcej zaburzeń w funkcjonowaniu społecznym niż starsze dzieci (8-12) i młodzież (13-18 lat) [76]. Ponad to stwierdzono, że dzieci z bólami głowy częściej opuszczały szkołę i były mniej zadowolone z osiągnięć szkolnych niż dzieci zdrowe. W innym badaniu Powers i wsp., w którym wzięło udział 572 osób, stwierdzili, że bóle głowy u dzieci miały negatywny wpływ we wszystkich obszarach funkcjonowania w porównaniu z dziećmi zdrowymi, a gorzej wypadły dzieci z przewlekłymi codziennymi bólami głowy [77]. Ponad to obecność migrenowych bólów głowy u dzieci miało podobny wpływ na QL jak u dzieci z zapaleniem stawów czy z rakiem [77].

W badaniu Koller i wsp. oceniający QL wzięło udział 76 dzieci, w tym u 37 rozpoznano migrenę, a pozostała grupa była grupą kontrolną [78]. Stwierdzono, że dzieci $\mathrm{z}$ migreną $\mathrm{w}$ porównaniu do swoich rówieśników częściej jadały nieregularnie i rzadziej wykonywały ćwiczenia fizyczne. Dodatkowo stwierdzono, że dzieci z migreną miały istotnie niżą QL w funkcjonowaniu szkolnym i znacznie częściej miały gorsze wyniki w nauce niż dzieci bez migreny [78].

Celem badania Slater i wsp. była ocena współistniejących diagnoz psychiatrycznych u młodzieży z przewlekłym codziennym bólem głowy oraz zbadanie zależności pomiędzy stanem psychiatrycznym a nasileniem objawów bólów głowy oraz niepełnosprawnością związaną z bólem głowy [79]. W wynikach stwierdzono, że prawie 30\% dzieci z przewlekłym codziennym bólem głowy spełniało kryteria co najmniej jednego rozpoznania choroby psychiatrycznej, a 35\% dzieci spełniało takie kryteria w ciągu całego życia. Slater i wsp. nie zauważyli istotnego związku między stanem psychiatrycznym a częstotliwością, czasem 
trwania lub nasileniem bólu głowy. Ponad to dzieci z co najmniej jednym rozpoznaniem psychiatrycznym w ciągu całego życia miały większą niepełnosprawność funkcjonalną i gorszą QL niż dzieci bez diagnozy psychiatrycznej. W podsumowaniu autorzy stwierdzili, że w przeciwieństwie do badań przeprowadzonych na dorosłych z przewlekłymi bólami głowy, większość młodzieży nie jest narażona na podwyższone ryzyko współistnienia diagnozy psychiatrycznej. Zauważono jednak, że pacjenci ze współistniejącą diagnozą psychiatryczną mają wyższy poziom niepełnosprawności związanej z bólem głowy i gorszą QL [79].

Ciekawe badanie wykonali Soee i wsp., których celem była ocena skuteczności specjalistycznego wielodyscyplinarnego programu leczenia dzieci z bólem głowy zgodnie z wytycznymi Europejskiej Federacji Towarzystw Bólu Głowy (ang. European Headache Federation, EHF) [80, 81]. W skład zespołu opiekującego się chorymi dziećmi wchodzili lekarze, pielęgniarki, fizjoterapeuci i psycholodzy. Do programu włączono 169 dzieci z bólami głowy, które kontrolowano po 6 i 12 miesiącach, a oceny dokonywano między innymi przy pomocy kwestionariuszy PedMIDAS i PedsQL. Dzieci z bólami głowy zostały podzielone na dzieci z: migreną, z bólami głowy typu napięciowego, z migreną i z bólami głowy typu napięciowego, z bólami głowy nadużywające leków przeciwbólowych, z innymi typami bólów głowy, z częstymi epizodycznymi bólami głowy typu napięciowego i z przewlekłymi bólami głowy typu napięciowego. U 50\% dzieci po sześciu miesiącach częstość bólów głowy zmniejszyła się powyżej 50\%. Stwierdzono znaczny spadek częstości bólu głowy we wszystkich sześciu grupach typów bólów głowy oraz istotny wzrost jakości życia dla całej grupy badanej [80].

Depresja i zaburzenia lękowe są uważane za jeden z czynników nasilających bóle głowy, ale należy też pamiętać, że częste bóle głowy mogą prowadzić do negatywnych stanów emocjonalnych [82-84]. W wytycznych Amerykańskiej Akademii Neurologii dotyczących leczenia migreny u dzieci podkreślono możliwą skuteczność terapii poznawczo-behawioralnej w zapobieganiu migreny [85-88].

\section{KWESTIONARIUSZ CBCL}

W rozpoznawaniu zaburzeń zachowania w bólach głowy może być pomocny kwestionariusz CBCL [58, 89-94]. Kwestionariusz CBCL jest jednym z 3 odrębnych narzędzi służącym do dokonania całościowej diagnozy zaburzeń zachowania u dzieci i młodzieży [57, 58]. Poza oceną rodziców lub opiekunów dokonywaną za pomocą kwestionariusza CBCL istnieją dla starszej grupy wiekowej osobne kwestionariusze dla nauczycieli (TRF, ang. Teacher's Report Form) i dla samych pacjentów (YSR, ang. Youth Self-Report). Kwestionariusz CBCL jest przeznaczony dla dwóch grup dzieci w zależności od wieku, dla dzieci wieku 6-18 lat i dla dzieci młodszych w wieku 1,5-5 lat. Kwestionariusz dla najmłodszych dzieci wypełniają rodzice lub opiekunowie dziecka i dotyczy zachowań dziecka w ciągu ostatnich 2 miesiącach. Wersja dla przedszkolaków składa się ze 100 pytań a respondenci oceniają zachowanie dziecka w 3-punktowej skali (0 - nieprawdziwe,
1 - w pewnym stopniu lub czasami prawdziwe, 2 - bardzo prawdziwe lub często prawdziwe). Kwestionariusz dla starszych dzieci pozawala ocenić zachowania i emocje dziecka w ciągu ostatnich 6 miesięcy i składa się z dwóch części, pierwszej pozwalającej ocenić kompetencje i umiejętności dziecka oraz z drugiej oceniającej obszar emocjonalno-behawioralny. $\mathrm{W}$ sumie $\mathrm{w}$ kwestionariuszu CBCL przeznaczonym dla starszych dzieci zawartych jest 118 pytań. YSR opracowany jest dla dzieci w wieku od 11 do 18 lat i pozwala ocenić własne kompetencje oraz zaburzenia emocjonalno-behawioralne. Wszystkie trzy narzędzia, TRF, CBCL i YRS pozwalają uwzględnić całościową ocenę dziecka i jego rodziny. CBCL wyróżnia 8 skal zaburzeń zachowań: wycofanie, dolegliwości somatyczne, lęk i depresję, problemy społeczne, zaburzenia myślenia, zaburzenia uwagi, zaburzenia zachowania łamiące normy i zasady, agresję. Do zaburzeń eksternalizacyjnych zostały przyporządkowane skale zachowań łamiących normy i zasady oraz zachowanie agresywne, a do zaburzeń internalizacyjnych skale: wycofania, lęku i depresji, dolegliwości somatycznych. Suma punktów ze wszystkich skal określa występowanie danego problemu. Zaznaczenie odpowiednich wartości w ośmiu skalach i połączenie ich linią daje graficzny obraz zachowania dziecka. Wartości wyników oceniane są w skali percentylowej, osobnych dla różnych kategorii wiekowych i płci. Wynik poniżej 95 percentyla to strefa normalności, w której dziecko nie kwalifikuje się do występowania zaburzenia w danej skali, 95-98 percentyla jest strefą graniczną, a wynik powyżej 98 percentyla to strefa występowania objawów. Kwestionariusz CBCL został przetłumaczony i zwalidowany na język polski [95]. Wadą kwestionariusza CBCL jest tylko ocena zaburzeń zachowania a nie wszystkich aspektów QL [89, 92-94, 96].

W badaniu Galli i wsp., w którym wzięło udział 130 pacjentów z bólem głowy oraz 87 zdrowych dzieci przy pomocy kwestionariusza CBCL oraz Self Administrated Psychiatric Scales for Children and Adolescents, (ang. SAFA) stwierdzono, że internalizacja objawów (lęku i depresji) u dzieci koreluje z objawami matki [96]. We wnioskach autorzy stwierdzają, że ból głowy występuje w rodzinach z wysokim poziomem zaburzeń psychicznych, a matki są szczególnie wrażliwe na psychologiczne potrzeby swoich dzieci [96].

Ciekawą analizę na grupie 1856 rodzin przeprowadzili Arruda i Bigal, którzy oceniali zachowania dzieci i liczbę bólów głowy w zależności od częstotliwości bólów głowy u ich matek [92]. Stwierdzono, że dzieci z migreną częściej prezentowały nieprawidłowe wyniki w kilku skalach CBCL, w porównaniu z dziećmi bez migreny. Stan migrenowy u matki w niewielkim stopniu wpływał na ich dzieci, jednak gdy u matki występowały codzienne bóle głowy to zarówno dzieci z migreną, jak i bez migreny miały podobne wyniki w skali CBCL [92]. Na tej samej grupie pacjentów Arruda i wsp. zbadali behawioralne i emocjonalne objawy u dzieci w zależności od stanu i częstotliwości bólu głowy [58]. W porównaniu z grupą kontrolną, $\mathrm{u}$ dzieci z migreną istotnie częściej występowały nieprawidłowości w następujących domenach CBCL: somatycznej, 
lękowo-depresyjnej, społecznej, zaburzeń uwagi, internalizacji. Poza tym dzieci z migreną uzyskały gorszy wynik w całkowitym podsumowaniu w kwestionariuszu CBCL. Z kolei dzieci z bólem głowy typu napięciowego istotnie różniły się od grupy kontrolnej w tych samych domenach, ale z mniejszą częstością niż dzieci z migreną. U dzieci z migreną gorsze wyniki były zależne od częstotliwości bólu głowy, rasy i sytuacji ekonomicznej. U dzieci z bólami głowy typu napięciowego płeć, wiek i częstość bólów głowy były istotnie powiązane $\mathrm{z}$ nieprawidłowymi wynikami. W grupie dzieci z migreną nie stwierdzono różnic w zależności od wieku. We wnioskach autorzy stwierdzają, że objawy internalizacji są częstsze u dzieci z bólami głowy podczas gdy objawy eksternalizacji nie są znacząco częstsze w porównaniu do grupy kontrolnej [58].

W badaniu Mazzone i wsp. podzielono grupę 114 pacjentów na dzieci z napięciowymi bólami głowy, z migreną i grupę kontrolną, między innymi do oceny wykorzystano skalę CBCL [89]. Pacjenci z bólem głowy typu napięciowego i migreną mieli wyższe wyniki całkowite w skali CBCL, a także w podskalach internalizacji i eksternalizacji niż grupa kontrolna. Ponad to dzieci z bólami głowy typu napięciowego miały wyższe wyniki niż pacjenci z migreną, a także wykazywały wyższe wyniki w zakresie emocjonalności i nieśmiałości oraz niższe wyniki w nawiązywaniu kontaktów społecznych. Dzieci z bólami typu napięciowego miały większe trudności psychologiczne oraz z emocjami niż dzieci z migreną [89].

W artykule Balottini'go i wsp. wzięto pod uwagę 10 różnych badań oceniających za pomocy skali CBCL zachowanie dzieci z bólami głowy, 406 pacjentów z migreną, 230 z bólami głowy typu napięciowego i 488 pacjentów stanowiła grupa kontrolna. Na podstawie tej metaanalizy stwierdzono, że dzieci z migreną miały więcej objawów psychopatologicznych niż osoby zdrowe. Dzieci z bólami głowy typu napięciowego miały wyraźne zaburzenia w obszarze internalizacji w porównaniu do grupy kontrolnej. Nie stwierdzono istotnej różnicy $\mathrm{w}$ zaburzeniach zachowania między dziećmi z migreną i z bólami głowy typu napięciowego [93].

W badaniu oceniającym rozpowszechnienie i czynniki ryzyka bólów głowy u dzieci w wieku 6-18 lat w północnych Włoszech Pogliani i wsp. stwierdzili, że nawracające bóle brzucha, osłabienie ruchowe i choroba lokomocyjna były istotnie częstsze u dzieci z pierwotnymi bólami głowy w porównaniu do grupy dzieci ze sporadycznymi bólami głowy [97]. Ponad to zaburzenia lękowe i depresyjne były częstsze $\mathrm{w}$ grupie z pierwotnym bólem głowy i sporadycznym bólem głowy w porównaniu do grupy zdrowej. Dzieci z pierwotnymi bólami głowy częściej przejawiały objawy agresji niż w grupie kontrolnej i u dzieci ze sporadycznymi bólami głowy. 72,5\% badanych z pierwotnym bólem głowy i 58,4\% dzieci ze sporadycznym bólem głowy przyjmowało leki łagodzące ból, najczęściej przyjmowanym lekiem był paracetamol [97]. Pogliani i wsp. stwierdzili różnice $\mathrm{w}$ zależności od płci u dzieci z pierwotnymi bólami głowy, dziewczęta wykazywały więcej cech depresyjnych i lękowych niż chłopcy.

\section{PODSUMOWANIE}

Kwestionariusze QL pozwalają zobiektywizować wpływ bólów głowy u dzieci na ich różne strefy życia, takie jak samopoczucie, codzienną aktywność, naukę, interakcje z rówieśnikami i relacje z rodzicami. Poza tym mogą też posłużyć jako narzędzia do planowania opieki, oceny skuteczności leczenia, a także mogą wpłynąć na indywidualizację leczenia. Wśród dostępnych w piśmiennictwie kwestionariuszy QL do oceny bólów głowy u dzieci najczęściej używane to PedMIDAS, PedsQL, CBCL i QLH-Y. Z uwagi na prostotę, szybkość wykonania oraz faktyczne odzwierciedlenie codziennego funkcjonowania pacjenta $\mathrm{z}$ bólami głowy kwestionariusz PedMIDAS wydaje się być bardzo użytecznym narzędziem w praktyce kliniczne. Należy jednak nadmienić, że brak walidacji i opracowania polskiej wersji tego kwestionariusza ogranicza jego powszechne wykorzystanie.

\section{PIŚMIENNICTWO}

[1] Barea L.M., Tannhauser M.,Rotta N.T.: An epidemiologic study of headache among children and adolescents of southern Brazil. Cephalalgia 1996; 16: 545-549; discussion 523.

[2] Zwart J.A., Dyb G., Holmen T.L., et al.: The prevalence of migraine and tension-type headaches among adolescents in Norway. The NordTrondelag Health Study (Head-HUNT-Youth), a large population-based epidemiological study. Cephalalgia 2004; 24: 373-379.

[3] Abu-Arafeh I., Razak S., Sivaraman B., et al.: Prevalence of headache and migraine in children and adolescents: a systematic review of populationbased studies. Dev Med Child Neurol 2010; 52: 1088-1097.

[4] Stovner L., Hagen K., Jensen R., et al.: The global burden of headache: a documentation of headache prevalence and disability worldwide. Cephalalgia 2007; 27: 193-210.

[5] Sillanpaa M.,Piekkala P.: Prevalence of migraine and other headaches in early puberty. Scand J Prim Health Care 1984; 2: 27-32.

[6] Krogh A.B., Larsson B.,Linde M.: Prevalence and disability of headache among Norwegian adolescents: A cross-sectional school-based study. Cephalalgia 2015; 35: 1181-1191.

[7] Ozge A., Bugdayci R., Sasmaz T., et al.: The sensitivity and specificity of the case definition criteria in diagnosis of headache: a school-based epidemiological study of 5562 children in Mersin. Cephalalgia 2003; 23: 138-145.

[8] Laurell K., Larsson B.,Eeg-Olofsson 0.: Prevalence of headache in Swedish schoolchildren, with a focus on tension-type headache. Cephalalgia 2004; 24: 380-388.

[9] Abu-Arefeh I.,Russell G.: Prevalence of headache and migraine in schoolchildren. BMJ 1994; 309: 765-769.

[10] Wober-Bingol C.: Epidemiology of migraine and headache in children and adolescents. Curr Pain Headache Rep 2013; 17: 341.

[11] Victor T.W., Hu X., Campbell J.C., et al.: Migraine prevalence by age and sex in the United States: a life-span study. Cephalalgia 2010; 30: 10651072.

[12] Tarasco V., Grasso G., Versace A., et al.: Epidemiological and clinical features of migraine in the pediatric population of Northern Italy. Cephalalgia 2016; 36: 510-517.

[13] Sillanpaa M.,Saarinen M.M.: Long term outcome of childhood onset headache: A prospective community study. Cephalalgia 2018; 38: 11591166.

[14] Arruda M.A.,Bigal M.E.: Migraine and migraine subtypes in preadolescent children: association with school performance. Neurology 2012; 79: 1881-1888.

[15] Lipton R.B., Manack A., Ricci J.A., et al.: Prevalence and burden of chronic migraine in adolescents: results of the chronic daily headache in adolescents study (C-dAS). Headache 2011; 51: 693-706.

[16] Wang S.J., Fuh J.L., Lu S.R., et al.: Chronic daily headache in adolescents: prevalence, impact, and medication overuse. Neurology 2006; 66: 193197.

[17] Aromaa M., Rautava P., Sillanpaa M., et al.: Familial occurrence of headache. Cephalalgia 1999; 25: 49-52. 
[18] Russell M.B., Ostergaard S., Bendtsen L., et al.: Familial occurrence of chronic tension-type headache. Cephalalgia 1999; 19: 207-210.

[19] Anttila P., Metsahonkala L.,Sillanpaa M.: School start and occurrence of headache. Pediatrics 1999; 103: 80.

[20] Lee L.H.,Olness K.N.: Clinical and demographic characteristics of migraine in urban children. Headache 1997; 37: 269-276.

[21] Stępień A.: Migrena i jej postacie kliniczne. Termedia, Poznań 2009

[22] Sompolska-Rzechuła A.: Jakość życia jako kategoria ekonomiczna. Folia Pomeranae Universitatis Technologiae Stetinensis. Oeconomica 2003; 71: $127-140$.

[23] Dalkey N.C.,Rourke D.L.: The Delphi procedure and rating quality of life factors. Univ. California LA, Los Angeles 1972.

[24] The World Health Organization: Constitution Of The World Health Organization. 1946

[25] The World Health Organization: Report of WHOQOL Focus Group Work. World Health Organization. Geneva 1993.

[26] Karski J., Słońska Z.: Promocja zdrowia. Sanmedia, Warszawa 1991.

[27] https://encyklopedia.pwn.pl/haslo/jakosc-zycia;3916390.html.

[28] Schipper H., Clinch J.J.,Olweny C.L.M.: Quality of life studies. Definitions and conceptual issues, in Quality of life and pharmacoeconomics in clinical trials. 2nd ed., B. Spilker, Editor. 1996, Lippincott-Raven Publishers: Philadelphia; 11-23.

[29] WHO: Constitution of the World Health Organization, Basic Documents, ed. 45. 2006.

[30] The World Health Organization Quality of Life Assessment (WHO0OL): development and general psychometric properties. Soc Sci Med 1998; 46: $1569-1585$

[31] Development of the World Health Organization WHOOOL-BREF quality of life assessment. The WHOOOL Group. Psychol Med 1998; 28: 551-558.

[32] Oleś M.: Jakość życia młodzieży w zdrowiu i w chorobie. Wydawnictwo KUL, Lublin 2010.

[33] The WHOOOL Group: The World Health Organization Quality of Life Assessment (WHOQOL): Development and General Psychometric Properties. Social Science and Medicine 1998; 46: 1569-1585.

[34] Taylor R.M., Gibson F.,Franck L.S.: A concept analysis of health-related quality of life in young people with chronic illness. J Clin Nurs 2008; 17: 1823-1833.

[35] Tobiasz-Adamczyk B.: Geneza zdrowia, koncepcje i ewolucja pojęcia jakości życia., in Jakość życia w chorobach układu sercowonaczyniowego. Metody pomiaru i znaczenie kliniczne., K.M. KaweckaJaszcz K, Tobiasz-Adamczyk B, Editor. 2006, Termedia: Poznań; 9-42

[36] Tobiasz-Adamczyk B.: Jakość życia uwarunkowana stanem zdrowia Nowe spojrzenie na chorego., in Socjologia medycyny. Podejmowane problemy, kategorie analizy., A. Ostrowska, Editor. 2006, IFiS PAN Warszawa; 113-144.

[37] Jaracz K.: Sposoby ujmowania pomiaru jakości życia. Próba kategoryzacii. Pieleg. Pol. 2001; 2: 219-226.

[38] Papiuć E.: Jakość życia- definicje i sposoby jej ujmowania. Curr Probl Psychiatry 2011; 12: 141-145.

[39] Ferrans C.E., Powers M.J.: Psychometric assessment of the Quality of Life Index. Res Nurs Health 1992; 15: 29-38.

[40] The WHOOOL Group: Development of the WHOOOL: rationale and current status. Int. J. Mental Health 1994; 23: 24-56.

[41] The WHOOOL Group: The World Health Organization Quality of Life assessment (WHOQOL): position paper from the World Health Organization. Soc. Sci. Med. 1995; 41: 1403-1409.

[42] Langeveld J.H., Koot H.M., Loonen M.C., et al.: A quality of life instrument for adolescents with chronic headache. Cephalalgia 1996; 16: 183-196; discussion 137

[43] Nodari E., Battistella P.A., Naccarella C., et al.: Quality of life in young Italian patients with primary headache. Headache 2002; 42: 268-274.

[44] Hershey A.D., Powers S.W., Vockell A.L., et al.: PedMIDAS: development of a questionnaire to assess disability of migraines in children. Neurology 2001; $57:$ 2034-2039

[45] Ravens-Sieberer U., Gosch A., Abel T., et al.: Quality of life in children and adolescents: a European public health perspective. Soz Praventivmed 2001; 46: 294-302.

[46] Raphael D., Rukholm E., Brown I., et al.: The Quality of Life Profile-Adolescent Version: background, description, and initial validation. J Adolesc Health 1996; 19: 366-375

[47] Bandell-Hoekstra I.E., Abu-Saad H.H., Passchier J., et al.: Coping and Quality of Life in relation to headache in Dutch schoolchildren. Eur J Pain 2002; 6: 315-321.
[48] Langeveld J.H., Koot H.M.,Passchier J.: Headache intensity and quality of life in adolescents. How are changes in headache intensity in adolescents related to changes in experienced quality of life? Headache 1997: 37: 37-42.

[49] Santanello N.C., Hartmaier S.L., Epstein R.S., et al.: Validation of a new quality of life questionnaire for acute migraine headache. Headache 1995; 35: 330-337.

[50] Abu-Saad H.H., Kroonen E.,Halfens R.: On the development of a multidimensional Dutch pain assessment tool for children. Pain 1990; 43: 249-256.

[51] Richard A., Henry P., Chazot G., et al.: [Quality of life and migraine. Validation of the OVM questionnaire in hospital consultation and in general medicine]. Therapie 1993; 48: 89-96.

[52] Hartmaier S.L., DeMuro-Mercon C., Linder S., et al.: Development of a brief 24-hour adolescent migraine functioning questionnaire. Headache 2001; 41: 150-156.

[53] Wober-Bingol C., Wober C., Uluduz D., et al.: The global burden of headache in children and adolescents - developing a questionnaire and methodology for a global study. J Headache Pain 2014; 15: 86.

[54] Hartmaier S.L., DeMuro-Mercon C., Linder S., et al.: Development of a brief 24-hour adolescent migraine functioning questionnaire. Headache 2001; 41: 150-156.

[55] Reid G.J., Gilbert C.A.,McGrath P.J.: The Pain Coping Questionnaire: preliminary validation. Pain 1998; 76: 83-96.

[56] Varni J.W., Seid M.,Kurtin P.S.: PedsQL 4.0: reliability and validity of the Pediatric Quality of Life Inventory version 4.0 generic core scales in healthy and patient populations. Med Care 2001; 39: 800-812.

[57] Achenbach T.: Manual for the CBCL/4-18 and profile. Department of Psychiatry, University of Vermont, Burlington 1991.

[58] Arruda M.A.,Bigal M.E.: Behavioral and emotional symptoms and primary headaches in children: a population-based study. Cephalalgia 2012; 32: 1093-1100.

[59] Hershey A.D., Powers S.W., Vockell A.L., et al.: Development of a patient-based grading scale for PedMIDAS. Cephalalgia 2004; 24: 844849

[60] Stewart W.F., Lipton R.B., Whyte J., et al.: An international study to assess reliability of the Migraine Disability Assessment (MIDAS) score. Neurology 1999; 53: 988-994.

[61] Stewart W.F., Lipton R.B., Kolodner K., et al.: Reliability of the migraine disability assessment score in a population-based sample of headache sufferers. Cephalalgia 1999; 19: 107-114; discussion 174

[62] Hershey A.D., Powers S.W., Vockell A.L., et al.: Effectiveness of topiramate in the prevention of childhood headaches. Headache 2002; 42: 810-818.

[63] Topcu Y., Hiz Kurul S., Bayram E., et al.: The Paediatric migraine disability assessment score is a useful tool for evaluating prophylactic migraine treatment. Acta Paediatr 2014; 103: 484-489.

[64] Fallah R., Fazelishoroki F.,Sekhavat L.: A Randomized Clinical Trial Comparing the Efficacy of Melatonin and Amitriptyline in Migraine Prophylaxis of Children. Iran J Child Neurol 2018; 12: 47-54.

[65] Pakalnis A., Kring D.,Meier L.: Levetiracetam prophylaxis in pediatric migraine--an open-label study. Headache 2007; 47: 427-430.

[66] Hershey A.D., Powers S.W., Vockell A.L., et al.: Coenzyme 010 deficiency and response to supplementation in pediatric and adolescent migraine. Headache 2007; 47: 73-80.

[67] Szperka C.L., VanderPluym J., Orr S.L., et al.: Recommendations on the Use of Anti-CGRP Monoclonal Antibodies in Children and Adolescents. Headache 2018; 58: 1658-1669.

[68] Abu-Arafeh I., Hershey A.D., Diener H.C., et al.: Guidelines of the International Headache Society for controlled trials of preventive treatment of migraine in children and adolescents, 1st edition. Cephalalgia 2019; 39: 803-816.

[69] Heyer G.L., Merison K., Rose S.C., et al.: PedMIDAS-based scoring underestimates migraine disability on non-school days. Headache 2014 54: 1048-1053.

[70] Bektas 0., Ugur C., Gencturk Z.B., et al.: Relationship of childhood headaches with preferences in leisure time activities, depression, anxiety and eating habits: A population-based, cross-sectional study. Cephalalgia 2015; 35: 527-537.

[71] https://www.pedsql.org/.

[72] Headache Classification Subcommittee of the International Headache S.: The International Classification of Headache Disorders: 2nd edition. Cephalalgia 2004; 24 Suppl 1: 9-160. 
[73] Talarska D.,Zgorzalewicz-Stachowiak M.: The influence of selected factors on the quality of life of children with headaches. Adv Med Sci 2007; 52 Suppl 1: 123-125.

[74] Talarska D.: Quality of life in healthy children and in children with tension headaches--a comparative analysis. Rocz Akad Med Bialymst 2005; 50 Suppl 1: 126-128.

[75] Talarska D., Michalak M., Talarska P., et al.: Children with epilepsy against their healthy peers and those with headaches: Differences-similarities. Neurol Neurochir Pol 2018; 52: 35-43.

[76] Powers S.W., Patton S.R., Hommel K.A., et al.: Quality of life in paediatric migraine: characterization of age-related effects using PedsOL 4.0. Cephalalgia 2004; 24: 120-127.

[77] Powers S.W., Patton S.R., Hommel K.A., et al.: Quality of life in childhood migraines: clinical impact and comparison to other chronic illnesses. Pediatrics 2003; 112: 1-5

[78] Koller L.S., Diesner S.C.,Voitl P.: Quality of life in children and adolescents with migraine: an Austrian monocentric, cross-sectional questionnaire study. BMC Pediatr 2019; 19: 164.

[79] Slater S.K., Kashikar-Zuck S.M., Allen J.R., et al.: Psychiatric comorbidity in pediatric chronic daily headache. Cephalalgia 2012; 32: 1116-1122.

[80] Soee A.B., Skov L., Skovgaard L.T., et al.: Headache in children: effectiveness of multidisciplinary treatment in a tertiary paediatric headache clinic. Cephalalgia 2013; 33: 1218-1228.

[81] Steiner T.J., Antonaci F., Jensen R., et al.: Recommendations for headache service organisation and delivery in Europe. J Headache Pain 2011; 12: 419-426.

[82] Merikangas K.R., Stevens D.E.: Comorbidity of migraine and psychiatric disorders. Neurol Clin 1997; 15: 115-123.

[83] Powers S.W.,Andrasik F.: Biobehavioral treatment, disability, and psychological effects of pediatric headache. Pediatr Ann 2005; 34: 461 465

[84] Gordon K.E., Dooley J.M., Wood E.P.: Self-reported headache frequency and features associated with frequent headaches in Canadian young adolescents. Headache 2004; 44: 555-561.

[85] Oskoui M., Pringsheim T., Billinghurst L., et al.: Practice guideline update summary: Pharmacologic treatment for pediatric migraine prevention: Report of the Guideline Development, Dissemination, and Implementation Subcommittee of the American Academy of Neurology and the American Headache Society. Neurology 2019; 93: 500-509.
[86] Eccleston C., Palermo T.M., Williams A.C., et al.: Psychological therapies for the management of chronic and recurrent pain in children and adolescents. Cochrane Database Syst Rev 2014: CD003968.

[87] Ernst M.M., O'Brien H.L.,Powers S.W.: Cognitive-Behavioral Therapy: How Medical Providers Can Increase Patient and Family Openness and Access to Evidence-Based Multimodal Therapy for Pediatric Migraine. Headache 2015; 55: 1382-1396.

[88] Powers S.W., Kashikar-Zuck S.M., Allen J.R., et al.: Cognitive behavioral therapy plus amitriptyline for chronic migraine in children and adolescents: a randomized clinical trial. JAMA 2013; 310: 2622-2630.

[89] Mazzone L., Vitiello B., Incorpora G., et al.: Behavioural and temperamental characteristics of children and adolescents suffering from primary headache. Cephalalgia 2006; 26: 194-201.

[90] Riva D., Aggio F., Vago C., et al.: Cognitive and behavioural effects of migraine in childhood and adolescence. Cephalalgia 2006; 26: 596-603.

[91] Salvadori F., Gelmi V.,Muratori F.: Present and previous psychopathology of juvenile onset migraine: a pilot investigation by Child Behavior Checklist. J Headache Pain 2007; 8: 35-42.

[92] Arruda M.A.,Bigal M.E.: Migraine and behavior in children: influence of maternal headache frequency. J Headache Pain 2012; 13: 395-400.

[93] Balottin U., Fusar Poli P., Termine C., et al.: Psychopathological symptoms in child and adolescent migraine and tension-type headache: a metaanalysis. Cephalalgia 2013; 33: 112-122.

[94] Operto F.F., Craig F., Peschechera A., et al.: Parenting Stress and Emotional/Behavioral Problems in Adolescents with Primary Headache. Front Neurol 2017; 8: 749

[95] Olesen J.,Steiner T.J.: The International classification of headache disorders, 2nd edn (ICDH-II). J Neurol Neurosurg Psychiatry 2004; 75: 808-811.

[96] Galli F., Caputi M., Gallucci M., et al.: Headache and psychological disorders in children and adolescents: a cross-generational study. Minerva Pediatr 2017; 69: 231-238.

[97] Pogliani L., Spiri D., Penagini F., et al.: Headache in children and adolescents aged 6-18 years in northern Italy: prevalence and risk factors. Eur J Paediatr Neurol 2011; 15: 234-240.

Adres do korespondencji:

Jędrzej Fliciński; Katedra i Klinika Neurologii Wieku Rozwojowego Uniwersytet Medyczny im. Karola Marcinkowskiego w Poznaniu ul. Przybyszewskiego 49, 60-355 Poznań

e-mail: flicinski@ump.edu.pl 